\title{
Incentives for Financial Risk Management in Vietnamese Enterprises: A Study on Their Determinants
}

\author{
NGUYEN KHAC QUOC BAO \\ University of Economics HCMC - nguyenbao@ueh.edu.vn
}

\section{ARTICLE INFO ABSTRACT}

Article history:

Received:

Aug. 042014

Received in revised form:

Oct. 302014

Accepted:

Mar. 262015

Keywords:

risk management,

financial risk,

derivatives.
This study aims to assess the factors affecting the incentives for financial risk management in Vietnamese enterprises. By employing multivariable binary logistic regression, the author examines the relationship between hedging decisions for firms' financial risks and their determinants, namely financial distress costs, tax, agency cost of debt, capital-market imperfections and growth opportunity, hedge substitutes, level of managerial utility, level of government influence, and size of firms. The results demonstrate that hedging decisions for financial risks have a positive correlation with costs of financial distress and managerial utility, and a negative correlation with government influence. These findings are agreeable to empirical results of previous researches that work out on the same case. 


\section{Introduction}

Against all expectations, risks transpire in any investment decisions or corporate trade/business activities and are likely to turn the managers' "sweet dreams" to "bitterness". Depending on the level of risk, it may bring about firm's financial damage, being its source of distress or even bankruptcy. Thus, risk management is a crucial point to be taken into consideration by all corporations in their own business. The increasingly complicated fluctuations in prices of materials, interest rate, and exchange rate have caused corporate financial risk to become more unpredictable. Particularly in the current stages of global instability, it is yet more difficult to forecast fluctuations in prices as well as changes in financial variables. Consequently, do corporations discover the role of financial risk management for their business?

In Vietnam, however, risk hedging has not been considerably concerned. The evidence is that until now derivatives market, one of the important hedging instruments, is still in a primary stage and mostly drives transactions via over-the-counter markets instead of an official one. Of 102 firms in its sample, according to Nguyen's (2008) study, only 28 firms apply derivatives instruments, whereas 74 firms do not. In recent times, notwithstanding, risk hedging generally as well as employment of derivatives particularly in Vietnamese corporations exhibits increasingly positive signs, one of which has been the approval of a scheme to build a derivatives market in 2014 .

For these reasons the study aims to analyze the factors that affect the incentives for Vietnamese enterprises' financial risk management, putting forward empirical evidence that examines and defines which determinants impact on corporate hedging decisions in Vietnam and thereby making suggestions for enterprises'/policy-makers' hedging operations amid the current volatile context.

\section{Theoretical framework and empirical evidence for determinants of hedging incentives for financial risk management}

In the previous studies the hedging incentives are separated into two kinds of theory: theory of maximizing shareholders value and that of maximizing management value.

\subsection{Theory of shareholder value maximization}

According to Warner (1977), and Smith and Stulz (1985), financial distress would result in a considerable increase in the bankruptcy costs, i.e. legal fees and the fact that 
managers give up their creating actual values. Shareholders, as a result, prefer to hedge risks (Campbell \& Kracaw, 1987) and financial distress costs are also a cause of fluctuations in market price of the firm (Mayers \& Smith, 1982; Stulz, 1984; Smith \& Stulz, 1985; Shapiro \& Titman, 1998; Haushalter, 2000). Through the reduction in fluctuations in cash flows and profits, risk hedging diminishes the probability of financial distress, thereby decreasing costs of financial distress.

In addition, firm value could possibly be even higher due to a rise in debt capacity for increased interest rate will enhance firm's tax shield (Brander \& Lewis, 1986; Maksimovic, 1988). Dobson and Soenen (1993) argue that by smoothing the future cash flows, risk hedging decreases the probability of bankruptcy. Such is proven by the empirical studies conducted by Dodle (1995) via the survey on 500 firms in 2002 in addition to Haushalter's (2000) examining the hedging policies of oil and gas manufacturers. These findings, hence, demonstrate that the relation between hedging and leverage is consistent with both the perspective on the reduction of funding costs resulting from hedging risks and Stulz's (1996) forecasts.

Agency cost of debt is referred to in the study by Jensen and Meckling (1976) which supposes that cash flow decrease reduces the agency cost. In the conflict over the agency problem the first to be initially contemplated is underinvestment. According to Jensen and Smith (1985), firm's high leverage might restrain its scope of investment owing to the fact that profits go primarily to bondholders.

In terms of the second - asset substitution, Jensen and Smith (1985) maintain that higher leverage grows more fascinating to managers in their transferring from safer to riskier projects since losses, if any, will be burdened with by these bondholders. Dobson and Soenen's (1993) study tackles the question of why managers hedge firm risk by invoking three agency cost problems: first, by smoothing cash flows, hedging reduces uncertainty, thereby lowering the firm's costs of debt; next, a less volatile cash flow tends to lessen risk-shifting agency problem; and third, hedging diminishes the probability of financial distress and increase duration of contractual relations between shareholders.

Furthermore, MacMinn and Han's (1990) research indicates that hedging improves risk shift; and while hedging, according to Bessembinder (1991) reduces the incentives to underinvest, Minton and Schrand (1999) conclude that cash flow volatility may lead to underinvestment. 
It is argued that undermined cash flow volatility allows a firm to decrease expected tax rates. Firm's after-tax value is a concave function of its pre-tax value when it faces a convex tax function. Smith and Stulz's (1985) study suggests that risk hedging may increase firm value by reducing expected tax rates. This has been mentioned by Zimmerman (1988), Gurel and Pyle (1984), and Nance, Smith and Smithson. (1993). In addition, there are numerous determinants that enhance the convexity of tax functions, including tax loss carry forwards and carrybacks, commercial and investment tax credits, and tax incentives. In their empirical research carried out with over 80,000 corporations from annual COMPUSTAT data, Graham and Smith (1996) indicate that firms facing tax-function convexity have an incentive for risk hedging. Moreover, while Mayers and Smith (1982) demonstrate that firms coming up with higher convexity are more likely to conduct risk hedging, Mian (1996) detects the impact of investment tax credits on firm's hedging ability.

As with reduced probability of financial distress, in accordance with Smith and Stulz's (1985) study, a firm can smooth its cash flows in order to avoid the effects of interrupted cash flows on corporate investment. The costlier external financing, the more incentives firms have for hedging, thereby evading cash flow decrease that badly affects investment activities. Thus, those which have high growth opportunities will eventually have more incentives for risk hedging.

The model proposed by Froot, Scharftein and Stein (1993) indicates that external finance can be costlier to firms than internal finance because of such causes as capitalmarket imperfections (Myers \& Mailuf, 1984), transaction costs, asymmetric information, etc. Additionally, there exists a correlation between internal cash flows and firm's investment opportunities, according to Hoshi, Kashyap and Scharfstein (1991).

Besides, a study by Getzy, Minton and Schrand (1997) on 372 out of 500 nonfinancial corporations in 1990 concludes that firms with greater growth opportunities and tighter financial constraints tend to use more derivatives to reduce variation in cash flow or earnings that might prevent them from investing in valuable growth opportunities. As stated by Gay and Nam (1998), "for firms with enhanced investment opportunities, derivatives use is greater when they also have relatively low cash stocks." Also, Allayannis and Ofek (2001) demonstrate that the larger R\&D costs firms have, the further employment of derivatives there would be. 


\subsection{Theory of managerial utility maximization}

Smith and Stulz (1985) insinuate that shareholders hire managers for reasons of their professional skills that may result in firm value increase, yet managers do not maximize shareholder value if they are not motivated by adequate incentives. Executive compensation agreements, hence, should be designed in the way enhanced firm value is synonymous with the managers' additional benefits. This results in the fact that managers' risk aversion can drive them to hedge for their own benefits.

Additionally, the existing literature reveals other hypotheses akin to the determinants of corporate risk hedging. For instance, Nance et al. (1993), Dolde (1995), Mian (1996), Getzy et al. (1997), and Haushalter (2002) also indicate that large-sized corporations tend to get involved in hedging as these may suffer from greater losses during encounters with risks, which leads to more incentives for such. In addition, hedging occurs when the achieved profits are greater than its costs. Besides, corporations, instead of implementing financial risk management by hedging, probably precede with policies on conservative cash holdings or maintain low leverage.

\section{Data and methodology}

The research data were collected mainly from the two sources: audited financial statements of the fiscal year ending Dec. 31, 2012 and surveys on risk hedging of Vietnamese corporations. Through emails and direct interviews with chief executive officers, chief financial officers, head of finance department or chief accountant the survey was implemented in late 2013 and early 2014 with 94 corporations. In addition to risk hedging activities of corporations, the survey content covered such other financial and non-financial information as the ratios of manager and/or state ownerships.

Then, multivariable binary logistic regression was employed to analyze the collected data. This regression model is selected because collected data only confirm whether risk hedging had been conducted and fail to define the scale of firm's hedging activity.

According to the studies by Warner (1977), Smith and Stulz (1985), Jensen and Meckling (1976), Dobson and Soenen (1993), Mayers and Smith (1982), Nance et al. (1993), Dolde (1995), Mian (1996), Getzy et al. (1997), and Haushalter (2000) which examine the incentives for risk hedging to maximize firm value and managerial utility or such other factors that affect these incentives as the size of firms or hedge substitutes, hedging depends on the determinants including costs of financial distress, tax function 
convexity, agency cost of debt, investment (growth) opportunities, hedge substitutes, managerial utility, government influence and firm's size. Additionally, the binary logistic regression model is selected because the dependent variable is a discrete one. The regression model, therefore, takes the following form:

$$
\begin{aligned}
\operatorname{Ln}\left(\frac{p}{1-p}\right)= & \alpha+\beta_{1} \text { FINCOST }+\beta_{2} \text { TAX }+\beta_{3} \text { AGCOST }+\beta_{4} C E F+\beta_{5} \text { SUBSTITUTE } \\
& +\beta_{6} \text { MNGUTIL }+\beta_{7} G O V+\beta_{8} \text { SIZE }+\varepsilon
\end{aligned}
$$

where:

$\mathrm{p} \quad$ : probability of hedging by the firm;

$1-\mathrm{p} \quad$ : probability of not hedging;

FINCOST : financial distress costs;

TAX : tax function convexity;

AGCOST : agency cost of debt;

CEF : market imperfections and external financing costs, investment/growth opportunity;

SUBSTITUTE : hedge substitutes;

MNGUTIL : managerial utility;

GOV : government influence; and

SIZE : firm's size.

The dependent variable representing firm's risk hedging decisions (Hedge) is a binary one: the variable takes the value of 1 and 0 for firms with and without valid hedging respectively. Firms supposed to hedge risk include not only firms that use derivatives but also those who employ other hedging strategies.

The independent variables represent the determinants of firm's risk hedging decisions: Based on past empirical results, the author considers eight indicators of these; the proxy variables with indicators used in place of each other and expected signs are illustrated in Table 1 below: 


\section{Table 1}

Description of research variables and expected signs

\begin{tabular}{|c|c|c|c|}
\hline Determinant & Proxy Variable & Proxy value & Expected sign \\
\hline \multirow{4}{*}{$\begin{array}{l}\text { Financial distress } \\
\text { costs }\end{array}$} & FINCOST1 & Ratio of total debt to total assets & \multirow{4}{*}{ Positive } \\
\hline & FINCOST2 & Ratio of total debt to equity & \\
\hline & FINCOST3 & $\begin{array}{l}\text { Ratio of total long-term debt to total } \\
\text { assets }\end{array}$ & \\
\hline & FINCOST4 & Ratio of total long-term debt to equity & \\
\hline $\begin{array}{l}\text { Tax function } \\
\text { convexity }\end{array}$ & TAX1 & $\begin{array}{l}\text { Total tax loss carry forwards, } \\
\text { carrybacks, tax incentives (VND } \\
\text { billion) }\end{array}$ & Positive \\
\hline \multirow{2}{*}{$\begin{array}{l}\text { Agency cost of } \\
\text { debt }\end{array}$} & AGCOST1 & Firm's credit rating & \multirow[b]{2}{*}{ Positive } \\
\hline & AGCOST2 & $\begin{array}{l}\text { Share of the firm owned by } \\
\text { institutional investors }\end{array}$ & \\
\hline \multirow{2}{*}{$\begin{array}{l}\text { Investment/growth } \\
\text { opportunity }\end{array}$} & CEF1 & $\begin{array}{l}\text { Ratio of investment cash flow to total } \\
\text { assets }\end{array}$ & \multirow{2}{*}{ Positive } \\
\hline & CEF2 & $\begin{array}{l}\text { Ratio of investment cash flow to total } \\
\text { revenue }\end{array}$ & \\
\hline \multirow[t]{2}{*}{ Hedge substitutes } & SUBSTITUTE1 & $\begin{array}{l}\text { Liquidity ratio (current assets/current } \\
\text { liabilities) }\end{array}$ & \multirow{2}{*}{ Negative } \\
\hline & SUBSTITUTE2 & $\begin{array}{l}\text { Quick ratio (quick assets/total current } \\
\text { liabilities) }\end{array}$ & \\
\hline Managerial utility & MNGUTIL1 & $\begin{array}{l}\text { Proportion of firm's equity owned by } \\
\text { managers }\end{array}$ & Positive \\
\hline $\begin{array}{l}\text { Government } \\
\text { influence }\end{array}$ & GOV1 & $\begin{array}{l}\text { Proportion of equity owned by the } \\
\text { State }\end{array}$ & Negative \\
\hline \multirow{2}{*}{ Firm's size } & SIZE1 & Total assets (VND billion) & \multirow{2}{*}{ Positive } \\
\hline & SIZE2 & Total revenue (VND billion) & \\
\hline
\end{tabular}




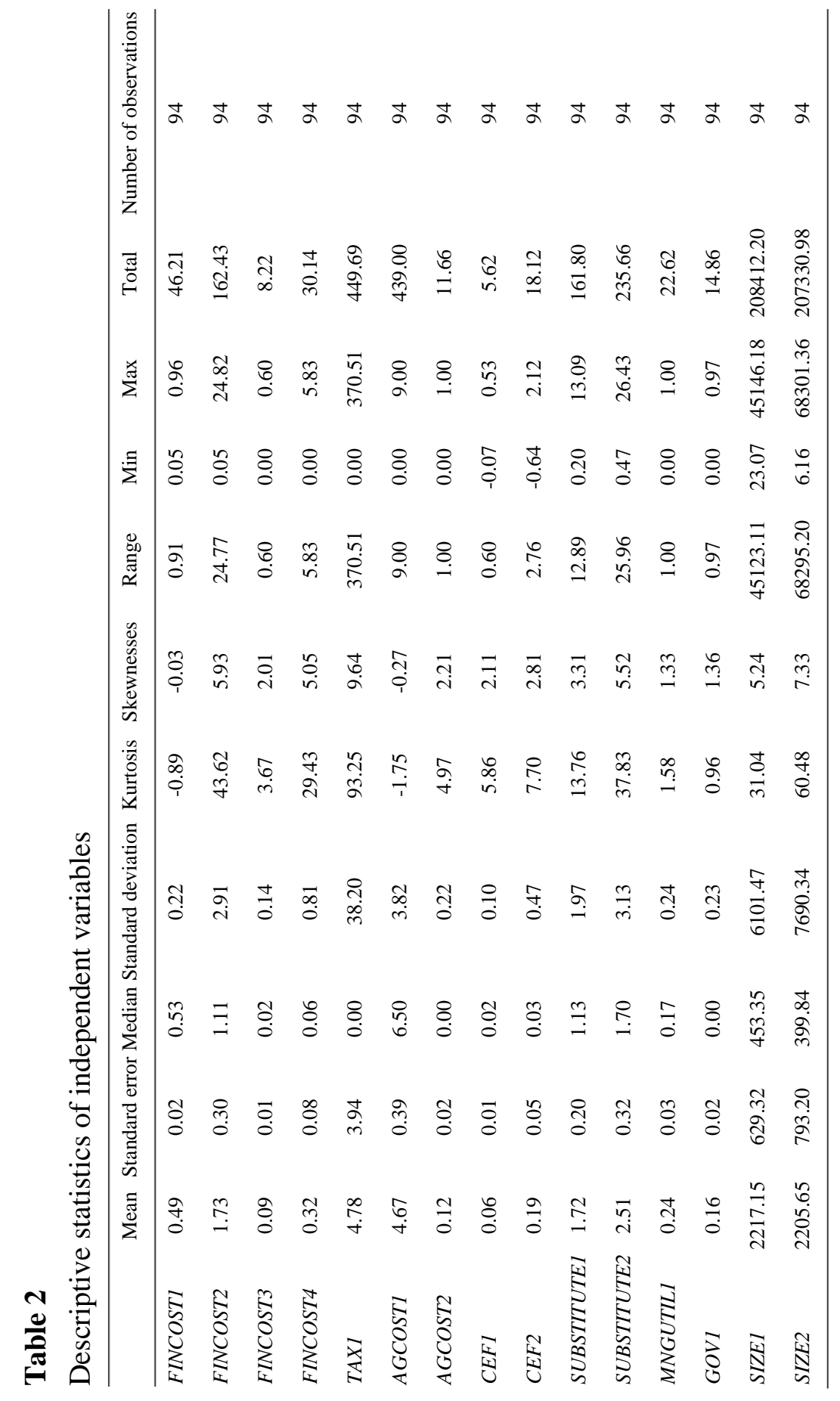




\section{Research results and discussion}

Prior to the application of multivariable regression model that examines the determinants of incentives for corporate financial risk management; the multicollinearity test is conducted with results as performed in Table 3 .

\section{Table 3}

Results of multicollinearity test for independent variables

Coefficients

\begin{tabular}{|c|c|c|c|c|c|c|c|c|}
\hline & \multirow{2}{*}{ Model } & \multicolumn{2}{|c|}{$\begin{array}{l}\text { Unstandardized } \\
\text { Coefficients }\end{array}$} & \multirow{2}{*}{$\begin{array}{c}\begin{array}{c}\text { Standardized } \\
\text { Coefficients }\end{array} \\
\text { Beta }\end{array}$} & \multirow{2}{*}{$\mathrm{t}$} & \multirow{2}{*}{ Sig. } & \multicolumn{2}{|c|}{$\begin{array}{l}\text { Collinearity } \\
\text { Statistics }\end{array}$} \\
\hline & & B & Std. Error & & & & Tolerance & VIF \\
\hline \multirow[t]{14}{*}{1} & (Constant) & .179 & .166 & & 1.075 & .286 & & \\
\hline & FINCOST1 & .832 & .270 & .366 & 3.083 & .003 & .377 & 2.654 \\
\hline & FINCOST2 & -.033 & .021 & -.196 & -1.559 & .123 & .337 & 2.965 \\
\hline & FINCOST3 & -.083 & .538 & -.023 & -.154 & .878 & .238 & 4.202 \\
\hline & FINCOST4 & -.044 & .096 & -.074 & -.464 & .644 & .211 & 4.739 \\
\hline & TAX1 & $1.295 \mathrm{E}-12$ & .000 & .101 & .535 & .594 & .149 & 6.718 \\
\hline & AGCOST13 & .202 & .265 & .060 & .763 & .448 & .862 & 1.160 \\
\hline & AGCOST14 & .184 & .256 & .054 & .718 & .475 & .923 & 1.084 \\
\hline & AGCOST15 & .097 & .197 & .040 & .495 & .622 & .798 & 1.254 \\
\hline & AGCOST16 & -.077 & .214 & -.032 & -.362 & .718 & .676 & 1.479 \\
\hline & AGCOST17 & -.007 & .130 & -.005 & -.054 & .957 & .719 & 1.391 \\
\hline & AGCOST18 & .068 & .109 & .057 & .623 & .535 & .632 & 1.583 \\
\hline & AGCOST19 & .098 & .123 & .076 & .797 & .428 & .585 & 1.710 \\
\hline & AGCOST2 & .003 & .002 & .131 & 1.567 & .122 & .756 & 1.323 \\
\hline
\end{tabular}


Coefficients

\begin{tabular}{|c|c|c|c|c|c|c|c|}
\hline \multirow{2}{*}{ Model } & \multicolumn{2}{|c|}{$\begin{array}{l}\text { Unstandardized } \\
\text { Coefficients }\end{array}$} & \multirow{2}{*}{$\begin{array}{c}\begin{array}{c}\text { Standardized } \\
\text { Coefficients }\end{array} \\
\text { Beta }\end{array}$} & \multirow{2}{*}{$\mathrm{t}$} & \multirow{2}{*}{ Sig. } & \multicolumn{2}{|c|}{$\begin{array}{c}\text { Collinearity } \\
\text { Statistics }\end{array}$} \\
\hline & B & Std. Error & & & & Tolerance & VIF \\
\hline CEF1 & .747 & .578 & .150 & 1.292 & .200 & .397 & 2.519 \\
\hline CEF2 & .069 & .139 & .067 & .495 & .622 & .294 & 3.397 \\
\hline $\begin{array}{l}\text { SUBSTITUT } \\
\text { E1 }\end{array}$ & -.009 & .028 & -.038 & -.342 & .734 & .423 & 2.364 \\
\hline $\begin{array}{l}\text { SUBSTITUT } \\
\text { E2 }\end{array}$ & .012 & .014 & .080 & .869 & .388 & .626 & 1.597 \\
\hline MNGUTIL1 & .006 & .002 & .317 & 3.701 & .000 & .724 & 1.380 \\
\hline GOV1 & -.013 & .002 & -.622 & -7.113 & .000 & .695 & 1.439 \\
\hline SIZE1 & $-3.721 \mathrm{E}-15$ & .000 & -.046 & -.260 & .795 & .167 & 3.979 \\
\hline SIZE2 & 7.813E-15 & .000 & .123 & .501 & .618 & .088 & 4.329 \\
\hline
\end{tabular}

a. Dependent Variable: Hedge

According to the test results, coefficient VIF of all variables is smaller than 10, which demonstrates that multicollinearity does not exist among the independent variables representing the determinants of incentives for corporate financial risk management. These are subsequently examined by the logistic regression, which is generally realized as follows:

"Hedge"=f("FINCOST,TAX,AGCOST,CEF,SUBSTITUTE,MNGUTIL,GOV,SIZE")

The regression result is shown in Table 4: 


\section{Table 4}

Testing results for determinants of incentives for risk management in Vietnamese enterprises

Omnibus Tests of Model Coefficients

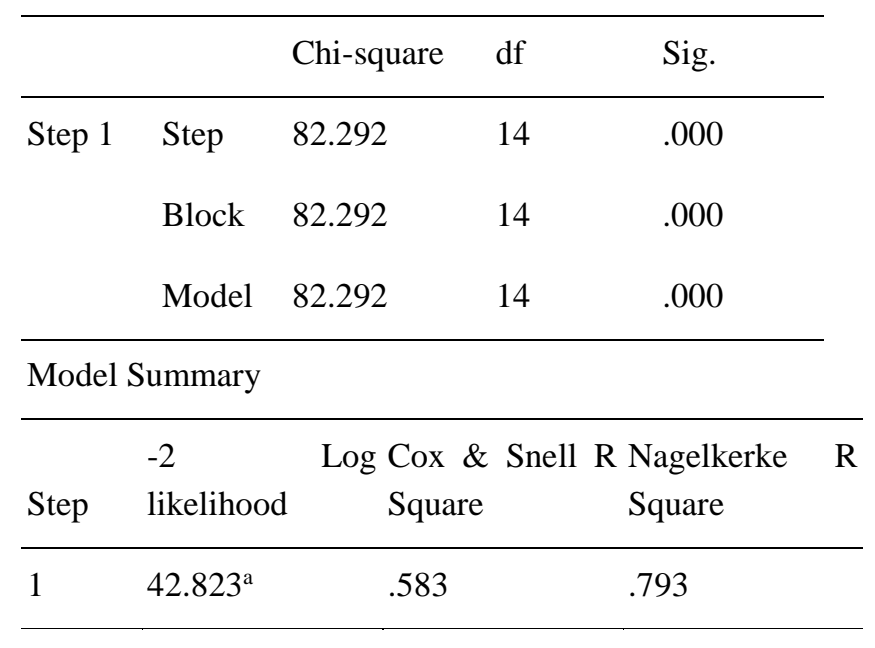

a. Estimation terminated at iteration number 20 because maximum iterations have been reached. Final solution cannot be found.

Classification Table

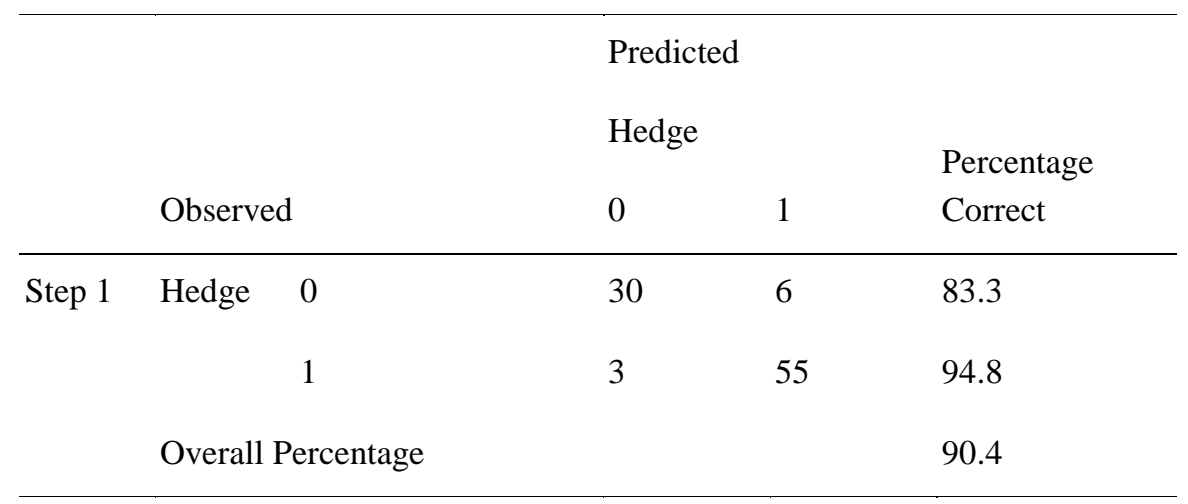

a. The cut value is .500 
Variables in the Equation

\begin{tabular}{|c|c|c|c|c|c|c|c|}
\hline & & B & S.E. & Wald & df & Sig. & $\operatorname{Exp}(B)$ \\
\hline \multirow[t]{15}{*}{ Step $1^{\mathrm{a}}$} & FINCOST1 & 6.087 & 2.506 & 5.899 & 1 & .015 & 440.197 \\
\hline & TAX1 & .000 & .000 & .000 & 1 & .994 & 1.000 \\
\hline & AGCOST13 & 2.976 & 7.226 & .170 & 1 & .680 & 19.610 \\
\hline & AGCOST14 & 2.379 & 2.369 & 1.008 & 1 & .315 & 10.793 \\
\hline & AGCOST15 & 14.793 & $1.966 \mathrm{E} 4$ & .000 & 1 & .999 & 2.659E6 \\
\hline & AGCOST16 & -3.345 & 2.322 & 2.075 & 1 & .150 & .035 \\
\hline & AGCOST17 & 1.736 & 1.291 & 1.808 & 1 & .179 & 5.675 \\
\hline & AGCOST18 & 1.175 & 1.070 & 1.205 & 1 & .272 & 3.237 \\
\hline & AGCOST19 & 1.383 & 1.586 & .760 & 1 & .383 & 3.988 \\
\hline & CEF2 & 2.929 & 1.933 & 2.295 & 1 & .130 & 18.701 \\
\hline & SUBSTITUTE2 & .082 & .176 & .214 & 1 & .644 & 1.085 \\
\hline & MNGUTIL1 & .137 & .044 & 9.727 & 1 & .002 & 1.147 \\
\hline & GOV1 & -.158 & .042 & 13.969 & 1 & .000 & .854 \\
\hline & SIZE1 & .000 & .000 & .608 & 1 & .436 & 1.000 \\
\hline & Constant & -4.068 & 1.664 & 5.978 & 1 & .014 & .017 \\
\hline
\end{tabular}

a. Variable(s) entered on step 1: FINCOST1, TAX1, AGCOST13, AGCOST14, AGCOST15, AGCOST16, AGCOST17, AGCOST18, AGCOST19, CEF2, SUBSTITUTE2, MNGUTIL1, GOV1, and SIZE1.

Accordingly, the most satisfactory variables (Table 4) include:

- FINCOST1: ratio of total debt to total assets, representing financial distress costs;

- TAX1: total tax loss carry forwards, carrybacks, tax incentives (VND billion), representing tax-function convexity; 
- AGCOST11-AGCOST19: nine dummy variables that measure firm's credit rating, representing the agency cost of debt;

- CEF2: ratio of investment cash flow to total revenue, representing capital-market imperfections, cost of external finance and investment/growth opportunities;

- SUBSTITUTE2: quick ratio, representing hedge substitutes;

- MNGUTIL1: proportion of firm's equity owned by managers, representing managerial utility;

- GOV1: proportion of firm's equity owned by the State, representing government influence; and

- SIZE1: total assets (VND billion), representing firm's size.

Omnibus Tests of Model Coefficients signify the results of testing the hypothesis of the overall model fit with sig. $=0.000$; thus, hypothesis $\mathrm{H} 0(\beta \mathrm{I}=0)$ is rejected. Regarding the sub table "Model Summary", the fact that the coefficient -2 log likelihood equals 42.823, which is not too high, demonstrates a sound fit level of the model compared to the whole. The accuracy of the model is also defined in "Classification Table", in which $83.3 \%$ and $94.8 \%$ of the firms that do and do not conduct risk hedging respectively are precisely predicted. As a result, the accuracy level of the whole model is approximately 90.4\%. Finally, in the sub table "Variables in the Equation", the Wald test demonstrates that such variables as FINCOST, MNGUTIL1, and GOV1 have sig. $<0.05$ and are thereby statistically significant. Accordingly, the logistic regression model can be rewritten as follows:

$$
\operatorname{Ln}\left(\frac{p}{1-p}\right)=-4.068+6.087 \text { FINCOST } 1+0.137 \text { MNGUTIL } 1-0.158 G O V 1
$$

where:

$\mathrm{p} \quad$ : probability of hedging by the firm;

$1-\mathrm{p} \quad$ : probability of not hedging;

FINCOST1 : ratio of total debt to total assets, representing financial distress costs;

MNGUTIL1 : proportion of firm's equity owned by managers, representing managerial utility; and

GOV1 : proportion of equity owned by the State, representing government influence. 
Akin to the multivariable analysis, the testing results for FINCOST1, MNGUTIL1 and GOV1 are appropriate to the aforementioned hypotheses and expected signs. The first significant variable in the model is the ratio of total debts to total assets (FINCOST1), which denotes financial distress costs. Fronting the variable is a coefficient with $\beta=6.087>0$, explaining that firms with higher and higher leverage tend to have more incentives for hedging because of the following two reasons: (i) the higher leverage would prompt risk hedging to reduce cash flow volatility, probability and costs of financial distress, which is in agreement with the studies by Warner (1977), and Smith and Tulz (1985); and (ii) hedging increases the debt capacity; therefore, risk management policies need to be associated with funding ones. The latter is concurrently consistent with Brander and Lewis (1986), and Maksimovic (1988), who demonstrate hedging contribution to increasing debt capacity, debt leverage and benefits from firms' tax shield. Also, the results agree with the empirical findings by Dolde (1985) and Haushalter (2000).

The second significant variable is proportion of firm's equity owned by managers (MNGUTIL1), representing managerial utility. The regression results show that coefficient in front of MNGUTIL1 is the one with $\beta=0.137>0$, implying that the higher the rate, the more incentives firms have to reduce cash flow volatility and protect shareholders' as well as managers' assets. Thus, the protection for individual assets associated with firms' assets is also regarded as an incentive for risk hedging. According to Smith and Stulz (1985), managers will not have any incentive for hedging without substantial benefits. As a result, once managers' assets are associated with those of shareholders, there are more incentives for managers to pre-commit to hedging against risk.

The last variable, GOV1, is the proportion of equity owned by the State, representing government effects on them. In front of this variable, coefficient $\beta=-0.158<0$ means that the bigger the government influence, the fewer incentives for hedging firms should have. In Vietnam, it is easy to find that firms with the high rate of state ownership are usually state-owned corporations privatized earlier or those in key strategic industries receiving a lot of preferential treatment and support from government. This leads to the fact that firms heavily influenced by the State have fewer incentives, complying with the hypothesis that firms with government influence/sponsorship are supposed to experience less economic effect and thereby managers' incentives to hedge risk would reduce. 
In addition, the other variables of the model are not statistically significant. Such contributory causes of the problem are: (i) Firms in Vietnam do not yet actually receive great tax incentives and major benefits from tax loss carry forwards and carrybacks; (ii) agency cost of debt is still low and thus bondholders do not take hedging into adequate consideration; (iii) firms have yet to focus on cash flow stability in order to take advantage of investment/growth opportunities but they still depend much on flows of loan capital instead; and (iv) maintaining reasonable liquidity and quick ratios has not been considered as a way for financial risk hedging.

To sum up, the three main determinants of corporate risk hedging decisions in Vietnam are finance distress costs (FINCOST), managerial utility (MNGUTIL) (positively correlated with risk hedging), and government influence (GOV) (negatively correlated with risk hedging).

\section{Conclusion}

The paper investigates the determinants of corporate hedging decisions in Vietnam. Its findings conclude three main determinants, including cost of financial distress, managerial utility and government influence. In addition to an overview of these determinants having been provided, there exist two shortcomings concerning this paper. First, the dataset employed in the study includes 94 firms, a number which is not large enough to perfectly cover all cases of Vietnam's corporate risk hedging. Additionally, as just a binary dependent one, the variable representing hedging activity can only determine whether or not firms can implement risk hedging instead of further reflecting their scope of hedging. This paper, hence, should carry implications of in-depth researches on hedging activities among Vietnamese firms.

\section{Recommendations}

Amid the context of today's complicated business environment and Vietnam's participation in the WTO as well as many implied risks, risk management and its related factors become an increasingly important matter to the firms. Due to the research results which indicate that there exists a positive correlation between financial distress costs and firm's hedging, firms with high leverage should focus on financial risk hedging and build a risk management procedure in accordance with firm's size, such as the one for internal control that restrains the probability and costs of financial distress encountered by these. 
Another issue is that there appears a positive correlation between managerial utility and risk hedging, explained by the fact that as managers' assets are associated with firm's health, its prosperity/development or even failure would then reflect their own "destiny." Consequently, necessary activities or decisions are proceeded with to protect firm's assets and also his own; and firms can give bonus to those for each typical target or allow them to buy firm's shares at good prices, thereby enhancing the assets as well as the managers' benefits. Accordingly, these given reasons aim to associate managers' richness with firm's prosperity and development, which may be turned into their incentive/responsibility. Besides, shareholders should examine and monitor management strategies, especially the process of risk hedging.

Last but not least, the inverse relationship between government influence and hedging is also deemed a very thought-provoking result, which shows that managers tend to depend much on government's support and protection. Thus, policy-makers should let firms to complete their own business without any longer depending much on government's support and provide mechanisms ensuring a separation between politicalsocial duties and profit earnings, which also restrain the aid, and firm's managers themselves should be aware of, instead of contingent on, building appropriate hedging mechanisms

\section{References}

Allayannis, G., \& Ofek, E. (2001). Exchange rate exposure, hedging, and the user of foreign currency derivatives. Journal of International Money and Finance, 20(2), 273-296.

Bessembinder, H. (1991). Forward contracts and firm value: Investment incentive and contracting effects. Journal of Financial and Quantitative Analysis, 26(4), 519-532.

Brander, J. A., \& Lewis, T. A. (1986). Oligopoly and financial structure. American Economic Review, 76(5), 956-970.

Campbell, T. S., \& Kracaw, W. A. (1987). Optimal managerial incentive contracts and the value of corporate insurance. Journal of Financial and Quantitative Analysis, 22(3), 315-328.

Davie, B., \& Zimmerman, D. (1988). Tax-exempt bonds after the South Carolina decision. Tax Notes, 39(13), 1573-1580.

Dobson, J., \& Soenen, L. (1993). Three agency-cost reasons for hedging foreign exchange risk. Managerial Finance, 19(6), 35-44.

Dolde, W. (1995). Hedging, leverage and primitive risk. Journal of Financial Engineering, 4(2), 187216.

Froot, K. A., Scharfstein, D. S., \& Stein, J. C. (1993). Risk management: Coordinating corporate investment and financing policies. Journal of Finance, 48(5), 1629-1658. 
Gay, G. D., \& Nam, J. (1998). The underinvestment problem and corporate derivatives use. Financial Management, 27(4), 53-69.

Getzy, C., Minton, B. A., \& Schrand, C. (1997). Why firms use currency derivatives. Journal of Finance, 52(4), 1323-1354.

Graham, J. R., \& Smith, C. W. (1996). Tax incentives to hedge. Journal of Finance, 54(6), 2241-2262.

Gurel, E., \& Pyle, D. (1984). Bank income taxes and interest rate risk management: A note. Journal of Finance, 39(4), 1199-1206, 1984.

Haushalter, G. D. (2000). Financing policy, basis risk, and corporate hedging: Evidence from oil and gas producers. Journal of Finance, 55(1), 107-152.

Hoshi, T., Kashyap, A., \& Scharfstein, D. (1991). Corporate structure, liquidity, and investment: Evidence from Japanese industrial groups. Quarterly Journal of Economics, 106(1), 33-60.

Jensen, C. M., \& Smith, C. W. (1985). Stockholder, manager, and creditor interests: Application of agency theory. Theory of the Firm, 1(1), 94-132.

Jensen, M. C., \& Meckling, W. H. (1976). Theory of the firm: Managerial behavior, agency cots and ownership structure. Journal of Financial Economics, 3(4), 305-360.

MacMinn, R. D., \& Han, L. M. (1990). Limited liability, corporate value, and the demand for liability insurance. Journal of Risk and Insurance, 57(4), 581-607.

Maksimovic (1988). Capital structure in repeated oligopolies. Journal of Economics, 19(3), 389-407.

Mayers, D., \& Smith, C. W. (1982). On the corporate demand for insurance. Journal of Business, 55(2), 281-296.

Mian, S. L. (1996). Evidence on corporate hedging policy. Journal of Financial and Quantitative Analysis, 31(3), 419-439.

Minton, B. A., \& Schrand, C. (1999). The impact of cash flow volatility on discretionary investment and the cost of debt and equity financing. Journal of Financial Economics, 54(3), 423-460.

Myers, S. C., \& Majluf, N. S. (1984). Corporate financing and investment decisions when firms have information that investors do not have. Journal of Financial Economics, 13, 187-221.

Nance, D. R., Smith, C. W., \& Smithson, C. W. (1993). On the determinants of corporate hedging. Journal of Finance, 48(1), 267-284.

Nguyen, T. N. T. (2008). How do firms in Vietnam implement financial risk management? (In Vietnamese). Journal of Economic Development, June No. 212, 38-44.

Shapiro, A. C., \& Titman, S. (1998). An integrated approach to corporate risk management. Midland Corporate Finance Journal, 3(2), 41-56.

Smith, C. W., \& Stulz, R. M. (1985). The determinants of firms' hedging policies. Journal of Financial and Quantitative Analysis, 20(4), 391-405.

Stulz, R. (1984). Optimal hedging policies. Journal of Financial and Quantitative Analysis, 19(2), 127140.

Warner, J. B. (1977). Bankruptcy cost: Some evidence. Journal of Finance, 32(2), 337-347. 